\title{
Family-based Social Skill Distance Learning for Children with Social Emotional Barriers (Need Analysis of Parents and Teachers)
}

\author{
Suharsiwi ${ }^{1}$, Weny Savitry S. Pandia ${ }^{2}$ \\ \{suharsiwi@umj.ac.id ${ }^{1}$, weny.sembiring@atmajaya.ac.id² \\ Universitas Muhammadiyah Jakarta, Indonesia ${ }^{1}$ \\ Unika Atma Jaya Jakarta, Indonesia ${ }^{2}$
}

\begin{abstract}
Teachers and parents play an important role in helping children with autism (Autism Spectrum Disorder/ASD) and Attention Deficit Hyperactivity Disorder (ADHD) to improve their social skill. Online learning is an alternative way for teachers and parents to help that children. This study aims to analyze parents' and teachers' need of family-based distance learning model, so the learning models and materials fit with children with ASD and ADHD and make them learn effectively. This study was conducted qualitatively through surveys and group interviews with convenience sampling. Survey's result of 30 parents and teachers found that $100 \%$ subjects agreed and needed a distance learning social skill model. For this reason, the distance learning model for social skill needs to be designed so that parents and teachers can learn about social skill independently, both at school and at home. From group interviews with 13 parents and 23 teachers, it was concluded that parents and teachers agreed and needed the learning material, namely social interaction, communication, and independence; but that learning materials needed to be improved. Recommendation was given to learning media, film storylines, and learning stages too, that are suitable on three themes namely: Let's Do It, Let's Show It, and Let's Go. The next stage is the drafting of maritirukan.com page based on this research's result.
\end{abstract}

Keywords: Learning Model, Distance Learning, Social Skill, ASD, ADHD.

\section{Introduction}

The problem of children with special needs is still an interesting study. Field research related to services of children with special needs in schools is still very much needed, especially regarding the development of learning strategies, models of services for children with special needs in inclusive schools, curriculum, and various child development programs. Research development of learning models for children with special needs is expected to produce a variety of outcomes that are useful for teacher and parent references, such as the publication of articles and textbooks. This can be additional information for interested parties in an effort to improve the services of children with special needs in school, by not letting go of parents' responsibilities in optimizing the development of children in the family. 
From the results of interviews with five PAUD teachers in Depok, there were complaints about the difficulty of teachers in teaching and training children with special needs regarding social skills and academic abilities. These difficulties are often caused by lack of communication and collaboration between school and home, such as parents ignoring bad habits, and not helping children practice at home. Conversely parents also complain that teachers are less skilled, lack knowledge of children with special needs, and children do not experience significant development after a long time in school.

Based on some previous research, the average child who has developmental obstacles, often have problems in social interaction, communication, and independent learning. Development of children's social skills is very important for children, parents will be so caring and really waiting for their children to greet friends, invite friends to play, say greetings, cooperate, do assignments independently, complete tasks until completion, and other social skills. Thus, the child is able to integrate and interact in various life environments, for example family, school, and social environment wherever he is [1].

The participation of researchers is needed especially in shaping creative programs that can be developed to help parents so that children can form positive behaviors and develop other abilities that are inhibited, in other words enabling children to "play" in the community environment. Model learning distance social skills is expected to help parents who assist children with special needs, so that children can develop a number of social skills. Thus, the child can interact, communicate well, and develop an attitude of independence. Distance learning is needed by parents and teachers in large urban areas, transition areas, rural areas, and also in remote villages that are far from current information.

This research is a continuation of previous research related to the development of social skills learning models for autistic children who incidentally are children with social barriers. The use of film media and picture cards that contain a number of social skills behaviors to be imitated and practiced by children for daily life.

This study aims to analyze the needs of users of the learning model that is parents and teachers who are accompanying special needs 'children. The research problems are formulated as follows:

a) What are the opinions of parents and teachers regarding distance learning for the development of ASD and ADHD children's social skills?

b) How does the distance learning model fit the needs of parents and teachers?

c) What do parents and teachers think about the themes and learning materials on the maritirukan.com?

\section{Literature Review}

\subsection{Social Skills}

Social skills are defined as a set of complex behaviors that enable individuals to engage in mutually beneficial reciprocal positive social interaction relationships [2]. According to Ormrod [3], social skills are a person's ability to think and behave effectively with others in social situations. Combs and Slaby in Cartledge and Milburn [4] define social skills as an ability to interact with others in existing social contexts in various ways that can be valued and socially accepted, and also provide benefits for themselves, others, and both. From the various definitions above it can be concluded that social skills are behaviors that appear to respond to 
existing situations, aiming at establishing relationships with others appropriately, in relationships/interactions that are beneficial to each individual.

Mc Intry in Oslond, Kold, and Rubin [5] states that social skills in children include: positive behavior and interactions with friends, appropriate behavior in the classroom, ways to deal with frustration and anger, and ways to overcome conflict with other people. Meanwhile Walker, McConnel, Holmes, Todis, Wakler, and Golden in Cartledge \& Milburn [4] divide social skills into five aspects, namely skills in the classroom, basic interactions, intimate relationships, making friends, and overcoming problems. Having a variety of social skills enables individuals to initiate, maintain, manipulate, or strengthen a social interaction, thus creating a social relationship. Social skills provide the actual way to do in a variety of social situations (e.g. making eye contact, saying hello, asking questions, listening and formulating answers, arranging the next meeting, and saying goodbye) [2].

\subsection{Children with ASD and ADHD}

Mash and Wolfe [6] stated ASD and its characteristics based on DSM V as a developmental disability that greatly affects social interaction and communication both verbal and non-verbal. Children with ASD experience deficits in communication and social interaction and there are repetitive patterns of behavior, interests and activities. This happens repeatedly and in various settings. Children with ADHD and ADD are children with attention deficit disorder. Children with ADD have the same characteristics as those classified as ADHD except for hyperactivity. Barriers to social interaction are generally experienced by children with ADHD. In Vaughn, Bos, and Schumm [7] it is stated that children with ADHD experience problems because they are impulsive, cannot control themselves, are difficult to regulate themselves, and cannot delay. This often causes the behavior is not in accordance with environmental demands, so that it has problems interacting.

\subsection{Social Skill Learning}

Cornish and Ross [8] state that when children can't control their behavior, they will have problems to meet social norms. Behavior problems can be overcome by observing others' behavior and learning through it. Behavior can also be influenced by consequences, such as praise or other rewards. Inappropriate behavior in children occurs due to distortions in the thought process that can inhibit the behavior, so missing skills must be taught to children. Vaughn and Bos [9] found that social diffusion can be fixed with social skills training. The purpose of this training is to teach children a complex response set that allows them to adapt to the many problems that occur in social situations. Goals of the training are: solve problems and make decisions quickly, adapt to situations that are new or unexpected, use coping strategies for responding to emotional upsets, communicate effectively with others, make and maintain friends, reduce anxiety, and reduce problem behavior. Social skills learning can help children improve information processing and restructure cognitive processes, and teach children to identify social cues verbally and non-verbally.

Hidayat [10] explained that social skills learning refer to the social learning model which is an extension of learning behavior theory. According to Bandura who pioneered social learning theory, humans can learn through selective observation and remembering the behavior of others through modeling. Learning through observation is more complex than just imitation, and is governed by four interrelated processes namely: attention, retention, motor reproduction, and motivational processes. The attention process determines what is 
considered; the retention process determines how experience is encoded in memory, the process of motor reproduction determines what behavior can be done; and the motivation process determines in what situations learning is translated into an action performance. In learning through observation, the imitation process of the thing observed depends on how attractive the model is so that it affects a person's behavior.

The experiment conducted by Bandura used a 5-minute film medium that displayed aggressive behavior, using real (human) models instead of cartoons. Real models (humans) and not cartoons have more impact on children's behavior [11]. Social modelling is effective to help children improve their social interaction abilities, helping others, and asking and giving information skills. McFall \& Lillesand argue social modeling has also been used extensively to develop assertive behavior and Chittenden explain effectively eliminate or reduce maladaptive behaviors such as aggression in children [10].

According to Seefeldt [12], social skills learning can be done through the following techniques: 1) Explain the concepts and behaviors that must be carried out; 2) Discuss ideas and behavior with children and ask them about ways that can be chosen to relate to others; 3 ) Practicing social skills, so children practice various behavioral concepts in real situations. In this social learning model children observe various concepts of behavior in real situations. Learning through observation is done by paying attention to the understanding process of children with unique special needs, while parents and teachers assist children in learning. Thus, the child develops an understanding of what is seen, heard and felt through the entire five senses.

The learning model through the maritirukan.com website is designed to assist learning for children in developing their social skills, with the assistance of parents. The aspects developed consist of aspects of attention/concentration, aspects of expression/emotion, effective communication, and independence. The learning model is carried out through several stages, namely: Concept Learning, Coaching, and Performance.

\section{Research Methods}

This research is a qualitative research with survey method through questionnaires and group interviews with parents of special needs 'children in Early Childhood Education and Primary School. Subjects in this study were 30 teachers and kindergarten parents in the Jakarta and Depok regions for the survey, and 13 parents and 23 teachers for group interviews. The sampling technique was convenience sampling.

Research procedures that have been carried out, namely asking a number of research questions related to the focus of research. In addition, group interviews were conducted to explore the problems and expectations of parents and Early Childhood Education and Primary School teachers. The data analysis method used is qualitative data analysis with the following steps: 1) Organizing data and coding; 2) Thematic analysis using a sequence of datakeywords-themes-categories-relationships between categories; 3) field data is compared with theoretical review and is used as a basis for analyzing by combining theory and facts in the field [13]. 


\section{Results and Discussion}

Based on a survey, the results showed that $100 \%$ of subjects agreed and needed a model of distance learning social skills to improve children's social skills. In Pandia [14] it is mentioned that parents have an important role in the care of children with special needs. Parents need to recognize what the child's obstacles are, then work out the right way so that the child's potential develops as well as possible. With the support of parents, children will develop optimally. From this opinion it is clear that the social skills' distance learning model is important for parents because parents have the tools to assist children who experience social skills' barrier. The teacher also considers this learning model important, because in Snowman and McCown [11] it is stated that teachers need a variety of assistive devices in learning, including technology-based. For students with special needs, a variety of learning media will greatly help students understand the material. The online social skills learning model through the film shown will increase students' motivation to absorb material.

From group interviews with parents and teachers the following results were obtained:

a) Opinions about distance learning for the development of ASD and ADHD children's social skills: Learning social skills is very important so that children are ready to engage in the community/family/school and are not considered to be different. Children need drilling to improve their social skills. Learning social skills especially learning with distance learning methods is important because it will help parents and teachers to teach children wherever and whenever. Often children want to interact with other people, but do not know the right way. Parents also sometimes do not know how to properly treat children and teach children. This can be overcome by having learning tools in the form of films that can be accessed online.

b) Suitability of the distance learning model for the needs of parents and teachers: Webbased learning is a good step and very important. Parents and teachers have easy access to materials as long as they have knowledge about information technology. Sometimes parents do not understand how to teach children. Parents need insight, but not all parents and children with special needs can obtain learning resources. With this website, parents can be very helped to add insight, especially if there is no direct source of information in their area. Teachers also really need this learning model. The material is actually already in the Thirteen Curriculum (Kurtilas), but via internet learning will take place both visually and auditorily so that it is more interesting for the child as well as the teacher and parents who accompany it, rather than just reading the module.

c) Opinions from parents and teachers about the themes and learning materials on the maritirukan.com:

- Parents and teachers assess the learning material that will be presented, namely social interaction, communication, and independence is appropriate but needs to be supplemented.

- Obtained input on learning media, film storylines, and stages of learning. Learning models can be in the form of films containing scenes of things that are directly done by children, it can also be a scene of a therapist or teacher who is dealing with children, for example children who are tantrums, so that parents and teachers can learn from here.

- Learning access must be widely open so that it is easily accessible.

- For parents, the material should be more on practical things and stimulation that needs to be done; while the teacher needs to add theories and terms that need to be known. 
- Once there is a page, it takes a community and tools that are interactive so that community members can communicate with each other to find solutions. There needs to be training first.

- There needs to be an evaluation to check whether the child has succeeded in his learning. Some tasks can be conveyed on the page, for example: asking children to go alone to a stall/supermarket, while parents wait at the gate of the house. Settings need to be adjusted to the area

According to Cornish and Ross [8], social skills learning requires an overview of children's social skills at this time. There are several things that need to be prepared, namely social skills checklist, interview and observation of children before learning so that parents and teachers can know in advance the stages of child development and provide appropriate programs. Associated with distance learning media on the maritirukan.com page, an instrument that measures the level of child development and tools for teachers and parents is needed in order to estimate the level of children's social skills, so they can display the most appropriate material for children.

Vaughn and Bos [9] state several basic principles regarding social skills learning, including: developing cooperative learning so students can develop their skills in class, involving other students in the process of social skills learning, and teaching the skills that children really need today. Distance learning through maritirukan.com page can be used as a complement to the things that teachers have done in class and parents' home. Teachers and parents choose a theme that will be displayed for children, so children's skills that have not been mastered yet can be reach by observation.

\section{Conclusion and Recommendation}

a) Improve maritirukan.com based on input that has been obtained so that it suits the user's needs. Learning remains packaged in the theme: Let's Do It, Let's Show it, and Let's Go, but adds and improves the settings and story line.

b) Complete instruments to assess the current condition of the child's social skills and evaluate the child's progress

c) Try out the pages that have been improved before being used as a medium for social skills' learning for children.

d) Parents can accompany children to watch video shows according to the theme needed.

e) Children can fill out their own evaluation sheets and get a number of expert advice needed there.

f) Video playback can be repeated many times by the child so the child can be better trained.

\section{References}

[1] S. Suharsiwi, "Pengembangan Model Pembelajaran Keterampilan Sosial Anak Autis di Tk B," J. Ilm. Visi, vol. 10, no. 1, pp. 1-8, 2015.

[2] A. Cotugno, Group interventions for children with autism spectrum disorder. London: Jessica Kingsley Publishers.

[3] J. E. Ormrod, E. M. Anderman, and L. H. Anderman, "Educational psychology: Developing learners," 2006. 
[4] G. Cartledge and J. F. Milburn, Teaching social skills to children and youth. Massachusetts: Allyn and Bacon, 1995.

[5] J. Oslond, D. Kolb, and I. Rubin, The organizational behavior reader. New Jersey: Prentice hall, 2000.

[6] E. J. Mash and D. A. Wolfe, Abnormal child psychology. Singapore: Cengage Learning Mayanti, A. (2003). Strategi visual dalam pendidikan ASD berkomunikasi secara efektif. Makalah Konferensi Nasional Autisme-1, Jakarta, 2003. 2016.

[7] S. Vaughn, C. S. Bos, and J. S. Schumm, Teaching students who are exceptional, diverse, and at risk in the general education classroom. Allyn \& Bacon, 2011.

[8] U. Cornish and F. Ross, Social skills training for adolescents with general moderate learning difficulties. London: Jessica Kingsley Publishers, 2004.

[9] C. S. Bos and S. Vaughn, Strategies for teaching students with learning and behavior problems. ERIC, 2009.

[10] D. R. Hidayat and A. N. Deden Zaenudin, "Teori dan aplikasi psikologi kepribadian dalam konseling," Bogor Ghalia Indones., 2011.

[11] J. Snowman and R. McCown, Psyhcology applied to teaching. Singapore: Cengage Lerning, 2015.

[12] C. Seefeldt and N. Barbour, Early childhood education: An introduction. Merrill Publishing Company, 1990.

[13] E. K. Poerwandari, Pendekatan kualitatif untuk penelitian perilaku manusia, 3rd ed. Depok: LPSP3 Fakultas Psikologi Universitas Indonesia, 2005.

[14] W. S. S. Pandia, Mengasuh anak spesial. Dalam Tim Dosen Fakultas Psikologi Unika Atma Jaya "Mempersiäpkan generasi milenial ala psikolog: Kiat-kiat pendidikan anak bagi orang tua dan guru." 2018. 